\title{
PAROSTEAL OSTEOSARCOMA WITH MYOCARDIAL METASTASIS 13 YEARS AFTER FOLLOW-UP
}

Telma M. Santos-Machado, Cláudia R. Mendes Oliveira, Alberto T. Croci, Ângelo Fernandes, Márcia Datz Abadi, André Mathias Baptista and Olavo Pires de Camargo

SANTOS-MACHADO TM et al. - Parosteal osteosarcoma with myocardial metastasis 13 years after follow-up. Rev. Hosp. Clín. Fac. Med. S. Paulo 58 (2):113-118, 2003.

PURPOSE: To report the case of a woman with a diagnosis of grade II (low grade) parosteal osteosarcoma with the occurrence of myocardial metastasis 13 years after resection, and to present a review of the existing literature on the subject.

METHODS: Description of the case and review of the literature.

CONCLUSION: The review leads to the conclusion that the occurrence of metastasis from parosteal osteosarcoma can occur in up to $38 \%$ of the cases, in spite of its relatively low aggressiveness. However, myocardial metastasis of a parosteal osteosarcoma is an event that was not found in the literature.

DESCRIPTORS: Parosteal. Osteosarcoma. Heart. Myocardial. Metastasis.

\section{INTRODUCTION}

Parosteal osteosarcoma (POS) is an uncommon, slow-growing variant of osteosarcoma (OS) that occurs on the surface of the bone, and its diagnosis is obtained using specific criteria ${ }^{1}$. Its evolution is relatively benign, it is usually treated by wide resection with good results, and it often does not require chemotherapy.

The metastatic form of the disease may occur in up to $38 \%$ of the cases a few months or many years after the initial treatment ${ }^{2}$. The low-grade type of POS seldom metastasizes; on the other hand, the dedifferentiated variant ${ }^{2-4}$ has high potential for distant metastasis, with the lung being the most common site. However, 14 cases of patients with cardiac OS metastases whose primary tumors were of the conventional variety in all cases are reported in the literature. This report describes a case of POS in a female patient who was initially treated by wide resection and developed late myocardial metastasis, and it also presents a review of the literature with regard to several aspects related to the occurrence of cardiac metastases in patients with OS.

\section{DESCRIPTION OF THE CASE}

A 26-year-old, white, female patient presented a slow-growing tumor in the right arm over a period of 5 years. The tumor was resected at an-

From the Institute of Orthopedics and Traumatology and the Department of Surgery - Thorax , Hospital das Clínicas, Faculty of Medicine, University of São Paulo.

Received for publication on July 08, 2002. other service, with no available information on surgical pathology (SP) findings.

Six months after the resection, there was a relapse of the lesion, at which time the patient sought our service.

After a simple X-ray that showed characteristics suggestive of POS (Fig. 1), the patient was biopsied, with the corresponding SP findings confirming a grade II POS (Fig. 2). The patient underwent wide resection of the proximal humerus and implantation of a nonconventional polyethylene endoprosthesis (Fig. 3). Chemotherapy was not indicated since it was a low-grade lesion. Thirteen years later at the annual follow-up exam, imaging exams revealed thoracic nodules, one of which was located in the cardiac topography (Figs. 4 and 5). When the thoracotomy was performed, 2 pulmonary nodules 


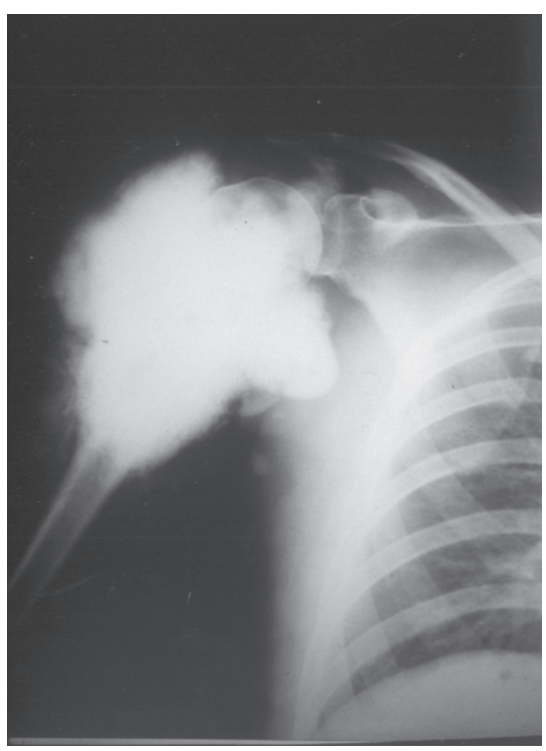

Figure 1 - X-ray showing parosteal osteosarcoma in proximal humerus.

were resected, at which time a $6 \mathrm{~cm}$ nodule was also discovered in the myocardial region in the atrioventricular septum next to the marginal and diagonal arteries, which was considered unresectable due to its location.

The SP examination of the lesions yielded grade II POS material, with characteristics similar to those of the primary tumor (Fig. 6).

The authors chose not to administer adjuvant treatment and decided on a strict follow-up protocol, with simple x-rays and thorax tomography at 3- and 6-month intervals, respectively (Fig. 7).

The patient is faring well 3 years after the surgery without additional symptoms or signs of tumor growth (Fig. 7).

\section{DISCUSSION}

POS is a malignant tumor of the bone tissue that was first described by Greschckter \& Copeland in $1951^{5}$, with an incidence corresponding to $1 \%$ of all bone tumors and $4 \%$ of $\mathrm{OS}^{2,6-9}$. The World Health Organization de-

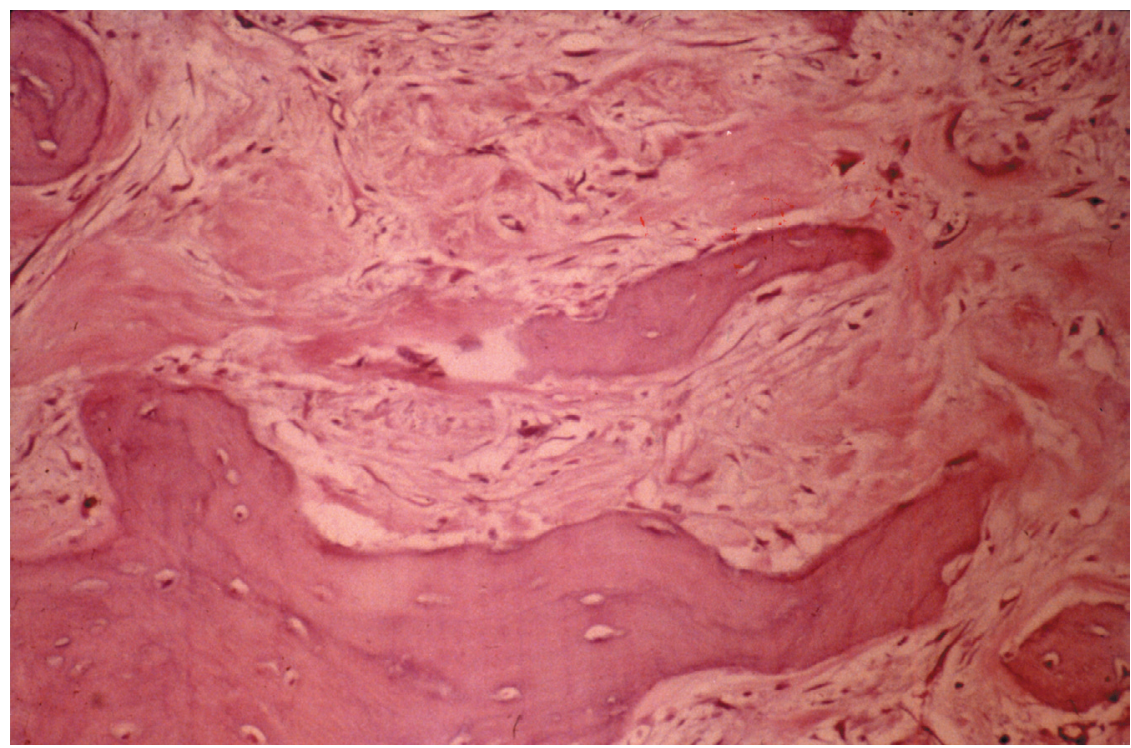

Figure 2 - Photomicrograph of juxtacortical osteosarcoma showing trabeculae of osteoid and osseous tissue and fibrous tissue with anaplastic cells (HE, orig. mag. X 200).

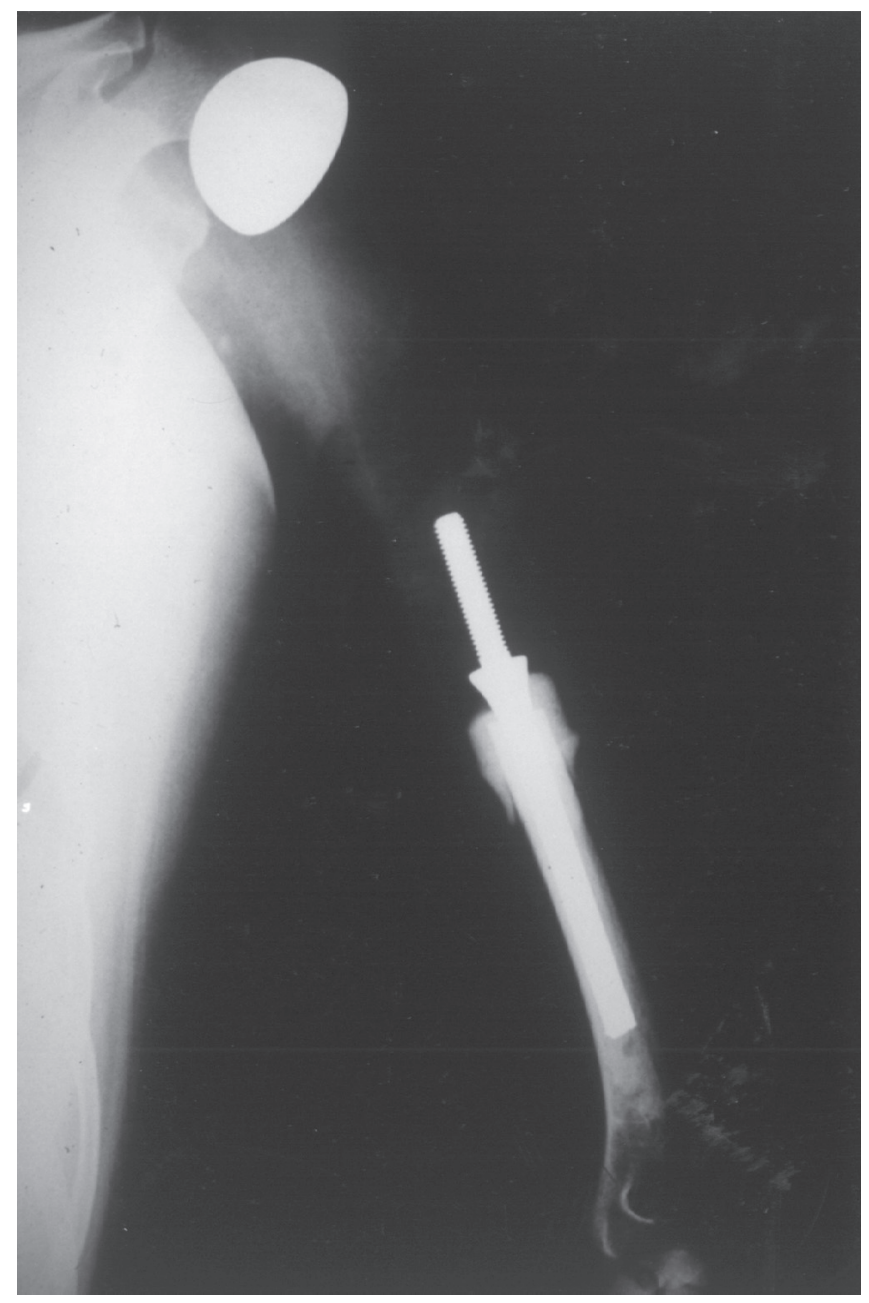

Figure 3 - X-ray showing the wide resection and endoprosthesis. 


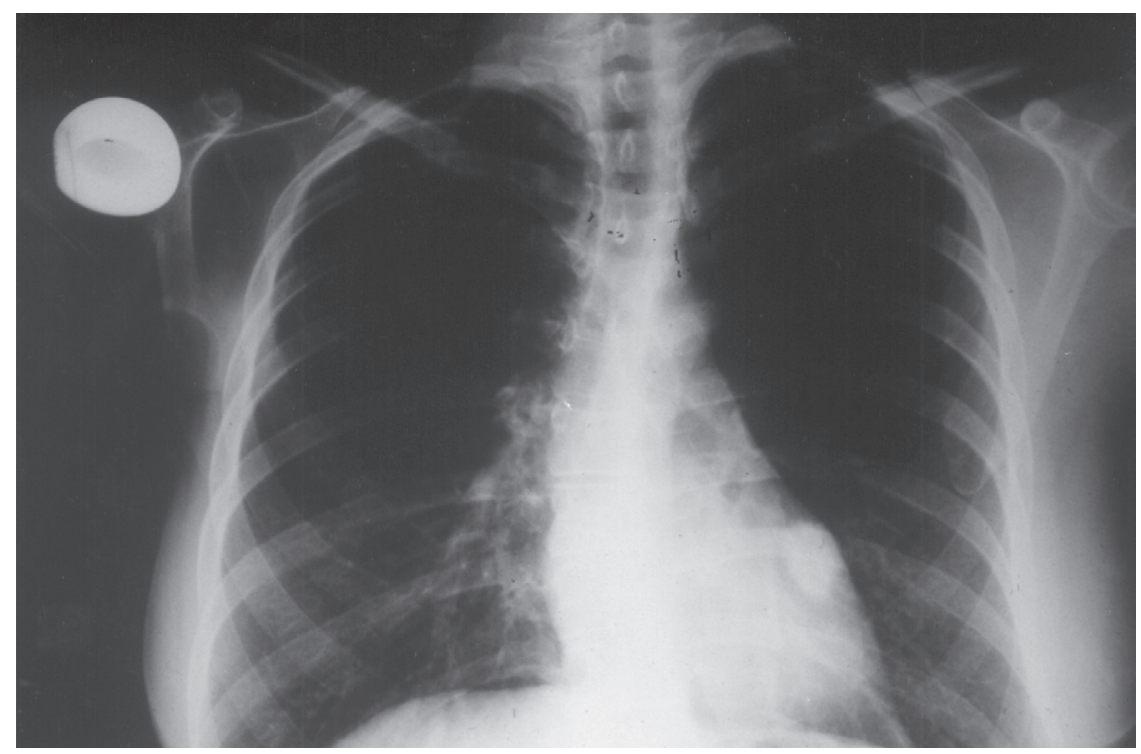

Figure 4 - Lung x-ray showing thoracic nodules.

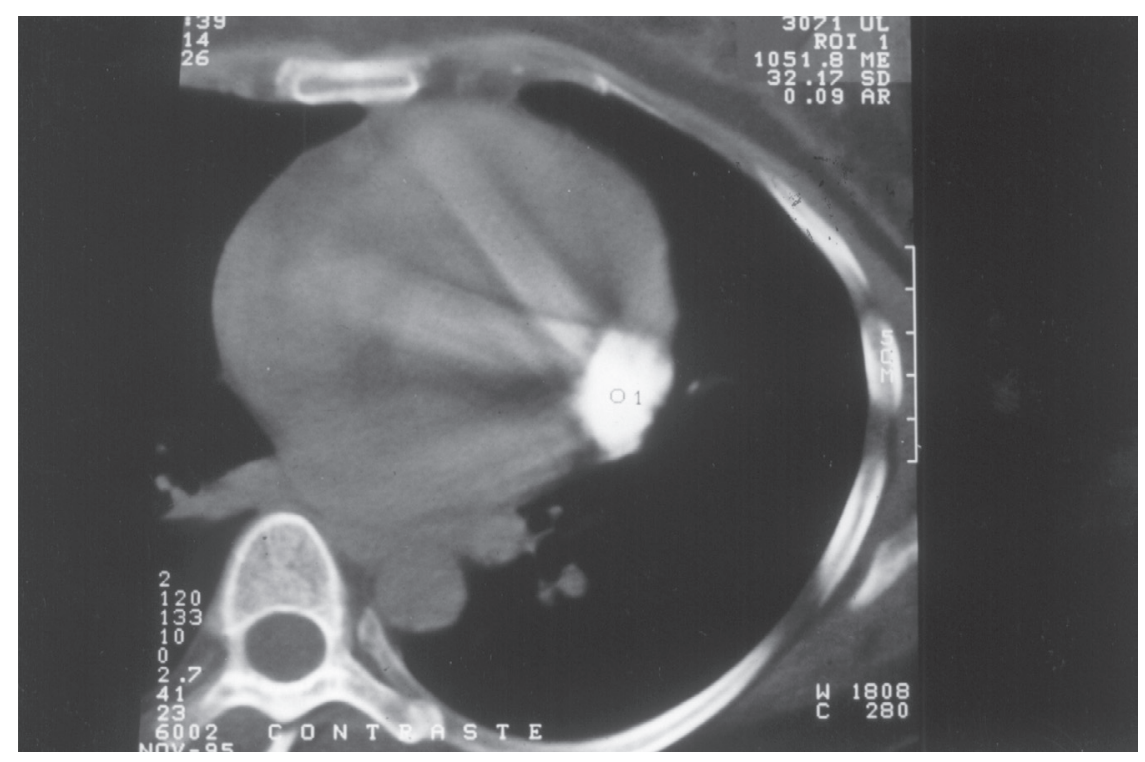

Figure 5 - Thoracic tomography showing cardiac topography of the nodule.

fines growth on external surfaces, medullar invasion of up to $25 \%$, high grade of differentiation, and low grade of malignancy as its diagnostic criteria $^{1}$. The highest incidence of POS occurs in the third and fourth decades of life predominantly in women, and the increase of local volume and pain are its clinical manifestations ${ }^{2,3,6}$. The diagnosis is suggested by clinical and radiographic findings and confirmed by biopsy and SP findings. Histopa- thology shows the presence of 3 components, consisting of fibrous, osseous, and cartilaginous tissues, with 3 grades of histological differentiation ${ }^{10}$. Grades I and II are characterized as low grade, also called conventional POS. However, POS might have a high-grade component (grade III). In such cases, the term dedifferentiated has been used. There can be dedifferentiation of a tumor from low to high grade; this is a complex process that could be re- lated to several local relapses ${ }^{3,10-12}$. Most cases manifest themselves at the time of diagnosis as tumors of local growth, and occurrences of initial metastatic disease are rare, which demonstrates the insidious development of this type of tumor ${ }^{2-5}$.

Treatment of POS is based upon the specific stage of the tumor and on whether it is intracompartmental or extracompartmental $\left(\mathrm{I}_{\mathrm{a}} \text { or } \mathrm{I}_{\mathrm{b}}\right)^{13}$. In intracompartmental tumors $\left(I_{a}\right)$, in which cortical and medullar invasion of the bone tissue does not occur, a transparietal resection can be performed, with better functional results and low rates of local relapse ${ }^{2}$, as long as strict controls of the resection margins are observed. In extracompartmental cases $\left(\mathrm{I}_{\mathrm{b}}\right)$, it is necessary to use wide resections, followed by reconstitution with homologous grafts or endoprostheses. Amputation is rarely indicated, and it is restricted to the cases of large volume with several relapses.

Later evolution to metastatic disease can occur in up to $38 \%$ of the patients, and metastasis is generally associated with cases of grade III $\mathrm{POS}^{2}$, medullar invasion, and several local relapses ${ }^{4}$. The occurrence of metastases with conventional tumors (low grade) is less frequent, and it is restricted to less than $20 \%$ of the cases ${ }^{3}$. The main site of metastases is the lung, with the abdomen and the central nervous system being reported less frequently $y^{2,3,7,8}$.

The period of latency between the primary tumor and the occurrence of metastases can vary from a few months to many years ${ }^{2-4}$; survival following metastasis varies from 6 to 32 months, with an average of 16 months ${ }^{2}$.

The presence of cardiac metastases is relatively rare, occurring in $3 \%$ to $10 \%$ of the cases, of which just $10 \%$ will present clinical or radiological manifestations that may suggest the diagnosis ${ }^{14-19}$. The main histological types of the cardiac metastases are 


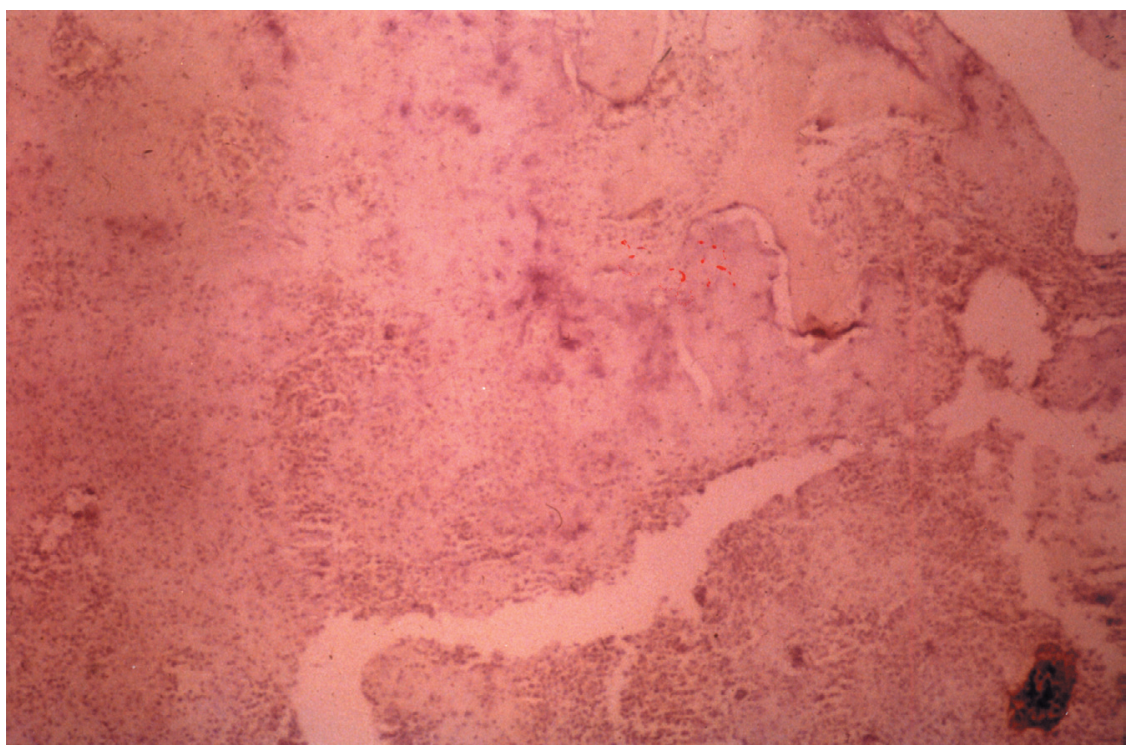

Figure 6 - Photomicrograph of thoracic specimen, showing formation of osteoid and osseous tissue (HE, orig. mag. X 100).

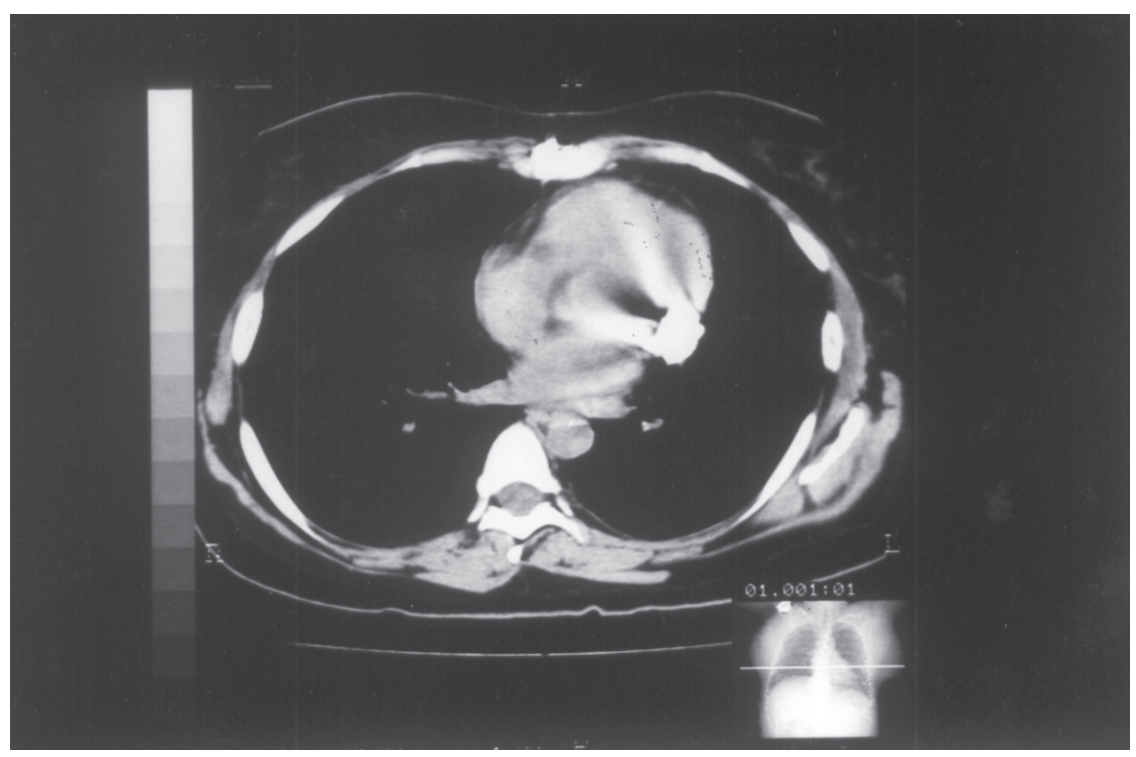

Figure 7 - The most recent thoracic tomography of the patient, showing stable disease 4 years later.

melanomas and carcinomas, especially of the bronchiogenic type ${ }^{20}$.

Concerning cases of OS, there are reports of several instances in which cardiac metastases were diagnosed ${ }^{14,21-}$ 29. The diagnoses in most of those cases were performed postmortem and were associated with a significant concurrence of pulmonary lesions $\mathrm{s}^{30}$. The preferential location in the heart is the purposes, is the production of bone tissue, which can be radiographically demonstrated as a circumscribed lesion with osseous density in the projection of the cardiac region ${ }^{14,31,32}$. Transesophageal echocardiography confirms the lesion, permitting visualization of the extent of involvement as well as any eventual secondary hemodynamic repercussions ${ }^{23}$. Final diagnosis is provided by the surgical pathology exam.

To the best of our knowledge, the occurrence of cardiac metastases from POS is not described in the literature. In addition, POS is a low-grade tumor with a low probability of causing systemic disease, which is one of the reasons for diagnosis after such extended periods of latency. Campanacci reports 9 occurrences of metastases in 41 cases of POS (21.9\%), 4 of which were discovered after latency periods of over 10 years (11.5-23 years). Of those cases, 3 were grade II, 2 presented involvement of the medullar channel, and all of them had undergone at least 2 manipulations ${ }^{4}$.

The previously described characteristics of low aggressiveness also account for the favorable prognosis for this patient, even without resection, which is considered by thoracic surgeons to be of high morbidity potential, and without adjuvant treatment. One option would be heart transplantation, but that was not indicated in our case, since there was no evidence of symptosis; additionally, having to keep the patient under immunosuppression adds additional risk of morbidity. The choice in this case was the follow-up based on clinical and radiographic parameters.

No evidence of cardiac or systemic symptoms has been found up to the time of the last evaluation 4 years later, confirming the low aggressiveness of the lesion. 
SANTOS-MACHADO TM e col. - Osteossarcoma parostal com metástase miocárdica após 13 anos de seguimento. Rev. Hosp. Clín. Fac. Med. S. Paulo 58(2):113-118, 2003.

OBJETIVOS: Os autores relatam um caso de uma paciente do sexo feminino, com diagnóstico de osteos- sarcoma parostal grau II (baixo grau), que evoluiu com a ocorrência de metástase miocárdica 13 anos após a ressecção do tumor e incluem uma revisão da literatura sobre o assunto.

MÉTODOS: Descrição do caso e revisão da literatura.

CONCLUSÕES: A revisão leva à conclusão que a existência de metás- tases oriundas do osteossarcoma parosteal pode ocorrer em até $38 \%$ dos casos, a despeito da sua relativa baixa agressividade. No entanto, a metástase miocárdica constitui um evento não relatado na literatura.

\section{DESCRITORES: Osteossarcoma.} Parostal. Metástases. Coração.

\section{REFERENCES}

1. ORGANIZACIÓN Mundial de la Salud, "Tipos histológicos de tumores ósseos" In: ROTO SADAG (ed) - Clasificasión histologica internacional de tumores. Ginebra, 1972. p 34.

2. CASSONE AE, CAMARGO OP, CROCI AT et al. - Osteossarcoma parostal: avaliação clínico-radiológica, anatomopatologia e fatores de prognóstico em 29 casos operados. Rev Bras Ortop 1998; 33(11):867-875.

3. SHETH DS, YASKO AW, RAYMOND AK et al. - Conventional and dedifferentiated parosteal osteosarcoma. Cancer 1996; 15:2136-2145

4. CAMPANACCI M, PICCI P, GHERLINZONI F et al. - Parosteal osteosarcoma. J Bone Joint Surg 1984; 66B (3): 313-321.

5. GERSCHICKTER CF, COPELAND MM - Parosteal osteosarcoma: a new entity. Ann Surg 1951; 133: 790-807.

6. EDEIKEN J, FARRELL C, ACKERMAN LV et al. - Parosteal osteosarcoma. Am J Roentgenol 1971;111: 579-583.

7. JOHNSON RI - Parosteal osteosarcoma. Clin Orthop 1970; 68: 78-83.

8. OKADA K, FRASSICA FJ, SIM FA et al. - Parosteal osteosarcoma. A clinicopathological study. J Bone Joint Surg [Am]1994; 76: $366-378$.
9. VAN DER HEUL RO, VAN RONNEN JR - Juxtacortical osteosarcoma. Diagnosis, differential diagnosis, treatment, and an analysis of eighty cases. J Bone Joint Surg [Am] 1967;116: $75-78$.

10. AHUJA SC, VILLACIN AB, SMITH J et al. - Juxtacortical (parosteal) osteogenic sarcoma. J Bone Joint Surg [Am]1977; 59: $632-647$.

11. LUCK U JR, LUCK JV, SCHWINN, CP - Parosteal osteosarcoma. A treatment-oriented study. Clin Orthop 1980; 153:92-105.

12. PENTON S, LOGAN PM, JANSEN DZ - Low-grade parosteal osteosarcoma of the ulna and dedifferentiation into high-grade osteosarcoma. Skel Radiol 1996; 25: 497-500.

13. ENNEKING WF, SPRINGFIELD O, GROSS M - The surgical treatment of parosteal osteosarcoma in long bones. J Bone Joint Surg [Am]1985; 67: 125-135.

14. SEIBERT RA, RETTENMIER CW, WALLER BF et al. Osteogenic sarcoma metastatic to the heart. Am J Med 1982; 73: $136-141$

15. ROBERTS WC, BODEY GP, WERLAKE PT - The heart in acute leukemia. A study of 420 autopsy cases. Am J Cardiol 1968; 21: $388-412$. 
16. GLANCY DL, MORALES JB, ROBERTS WC - Angiosarcoma of the heart. Am J Cardiol 1968; 21: 413-419.

17. GLANCY DL, ROBERTS WC - The heart in malignant melanoma. A study of 70 autopsy cases. Am J Cardiol 1968; 21: 555571 .

18. ROBERTS WC, GLANCY DL, DE VITA Jr. VT - Heart in malignant lymphoma (Hodgkin's disease, lymphosarcoma, reticulum cell sarcoma and mycosis fungoides). A study of 196 autopsy cases. Am J Cardiol 1968; 22: 85-107.

19. LINDSAY J JR, GOLDBERG SD, ROBERTS WC Electrocardiogram in neoplastic and hematologic disorders. In: RIOS, JC (ed): Clinical electrocardiographic correlations. Philadelphia, Saunders, 1977. p 225-242.

20. HERBERT PA, MEISEL AZ - Secondary tumors of the heart. Arch Path 1942; 34: 358-364.

21. DORFMAN HD, MICHAELIS GL - Cardiac metastasis in osteogenic sarcoma. Bull Hosp Joint Dis 1966; 27: 1-8.

22. LAURIAN AR - Intracardial tumor culture of osteogenic sarcoma with fatal tumor embolism. Am J Clin Pathol 1957; 27: 664691.

23. TSUNG-MING L, MING-FONG C, CHIAN-SUONG L et al. Role of transesophageal echocardiography in the management of metastatic tumors invading the left atrium. Cardiology 1997; 88: 214-217.

24. DALAL BL RAJER BS, DATTA BN et al. - Metastatic osteosarcoma of the heart: report of a case and review of literature. Ind J Cancer 1978;15: 84-86.
25. TAKATSU T, KINO M, SAWADA K - Metastatic osteosarcoma in heart: diagnostic problem of osteosarcoma metastasized to the heart (in Japanese/abstract) Nippon Rinsho 1979; 37: 402.

26. MAGOVERN GJ, YUSUF MF, LIEBLER GA et al. - The surgical resection and chemotherapy of metastatic osteogenic sarcoma of the right ventricle. Ann Thorac Surg 1980; 29: 76-80.

27. WISE NK, PETER RH, WECHSLER AS et al. - Right ventricular obstruction secondary to intracardiac metastatic osteosarcoma. Clin Cardiol 1980; 3: 200-203.

28. ATRA A, SHANKAR AG, PADHANI AR - Metastatic cardiac osteosarcoma - imaging features. BR J Radiol 1998; 71 (843): 336-339.

29. JAMES CL, BYARD RW, KNIGHT WB et al. - Metastatic osteogenic carcinoma to the heart, presenting as bacterial endocarditis. Pathology 1993; 25 (2): 190-192.

30. WILLIUS FA, AMBERG S - Two cases of secondary tumor of the heart in children in one of which the diagnosis was made during life. Med Clin Am 1930; 13: 1307.

31. JEFFREE M, PRIES C, HANDSISSONS HA - The metastatic patterns of osteosarcoma. Br J Cancer 1975; 32: 87-106.

32. URIBE-BOTERO G, RUSSEL W, SUTOW Wet al. - Primary osteosarcoma of bone - a clinicopathologic investigation of 243 cases with necropsy studies in 54. Am J Clin Pathol 1977; 67: 427-435 